\title{
The influence of the photoperiod on productive performance and survival of piabanha-of-Pardo (Brycon vonoi), hatchery
}

\author{
Marcelo Mattos Pedreira ${ }^{1 *}$ Deliane Cristina Costa ${ }^{1}$ Marianne Schorer $^{1}$
}

${ }^{1}$ Laboratório de Aquicultura e Ecologia Aquática, Departamento de Zootecnia, Universidade Federal dos Vales do Jequitinhonha e Mucuri (UFVJM), Rua da Glória, n 187, 39100-000, Diamantina, MG, Brasil. E-mail: marcelomattospedreira@gmail.com. "Corresponding author.

\begin{abstract}
This research aimed to verify the influence of the photoperiod on the performance and survival piabanha-of-Pardo (Brycon vonoi) larvae. Piabanha-of-Pardo larvae 24 hours post-hatch, with body weight of $2.44 \pm 0.02 \mathrm{mg}$, and total length of $7.82 \pm 0.46 \mathrm{~mm}$, were subjected to five different photoperiods: $0 \mathrm{~L}: 24 \mathrm{D}, 6 \mathrm{~L}: 18 \mathrm{D}, 12 \mathrm{~L}: 12 \mathrm{D}, 18 \mathrm{~L}: 6 \mathrm{D}$ and $24 \mathrm{~L}: 0 \mathrm{D}(871.12 \pm 92.65$ lux). Daily, the water temperature, dissolved oxygen $(D O)$, percentage of oxygen saturation, $\mathrm{pH}$, and water conductivity were monitored, and presented similar water quality values among tanks with distinct photoperiods, and within the range considered appropriate for the genus Brycon larvae. Piabanha-of-Pardo larvae have better productive performance and survival rate at longer photoperiods, over 6 hours of light and below 12 hours of light per day. The 9L:15D photoperiod, specified by the derived equation, is indicated for the piabanha larviculture, but researches with the species and the photoperiod need to be better studied.
\end{abstract}

Key words: Brycon vonoi, growth, larviculture, luminosity, survival.

Influência do fotoperíodo no desempenho produtivo e sobrevivência na criação de larvas de piabanha-do-Pardo (Brycon vonoi)

RESUMO: Este trabalho apresenta como objetivo verificar a influência do fotoperiodo sobre o desempenho e sobrevivência de larvas piabanha-do-Pardo (Brycon vonoi). As larvas de piabanha-do-Pardo com idade de $24 h$ pós-eclosão, com peso corporal de 2,44 $\pm 0,02 m g$, e comprimento total de 7,82 \pm 0,46mm, foram submetidas a cinco diferentes fotoperiodos: 0L:24E, 6L:18E, 12L:12E, 18L:6E e 24L:0E (871,12 \pm 92,65 lux). Diariamente a temperatura da água, oxigênio dissolvido, percentagem de saturação de oxigênio, pH, e condutividade da água foram monitorados. Estes apresentaram valores similares entre os aquários com distintos fotoperiodos, e dentro da faixa considerada, adequada para as larvas do gênero Brycon. As larvas de piabanha-do-Pardo apresentam melhor desempenho produtivo e taxa de sobrevivência em fotoperíodo mais longos, acima de 6 horas de luz e abaixo de 12 horas de luz. O fotoperíodo de 9L:15E, especificado pela equação derivada, é indicado para a larvicultura da piabanha, mas as pesquisas com a espécie e o fotoperiodo precisam ser melhor estudadas.

Palavras-chave: Brycon vonoi, crescimento, larvicultura, luminosidade, sobrevivência.

\section{INTRODUCTION}

The Brycon species, such as B. amazonicus, $B$. insignis and $B$. orbignianus are commercially important for fisheries and human consumption (HILSDORF et al., 2008), as well as the piabanhaof-Pardo, B. vonoi (LIMA, 2017). This endemic species of the basin of the Pardo River, has its natural population in decline, participating in restocking programs. However, reports about species biology are still scarce (CORASPE-AMARAL et al., 2012) requiring additional knowledge of the biological factors that influence the larvae development to create productive protocols.

The photoperiod has a great influence in fish larvae development, and induces different responses (SCHÜTZ \& NUÑER, 2007; FREITAS et al., 2008; SHAN et al., 2008; MACIEL et al., 2010). Positive effects have been observed in growth and survival under continuous light (MOUSTAKAS et al., 2004), intermediate photoperiods (BEZERRA et al., 2008), and complete darkness (PIAIA et al., 1999; SCHÜTZ \& NUÑER, 2007), whereas the responses vary according to the species and their development stage. 
Larvae of Brycon exhibit a cannibalistic behaviour. Theyare visual predators and the dark environments can affect its productive performance and influence the ability to catch live food (PEDREIRA et al., 2008). However, despite of the fact that the piabanha-of-Pardo larva is a visual predator, it is unknow how the photoperiod influences its performance, 24 hours after hatching (COSTA, 2011).

Therefore, the present study aimed to investigate the influence of photoperiods on the growth performance and survival of the piabanhaof-Pardo larvae.

\section{MATERIAL AND METHODS}

The experiment was conducted at CEMIG hydroelectric station in Machado Mineiro District, Municipality of Águas-Vermelhas (MG) $\left(15^{\circ} 44^{\prime} \mathrm{S}\right.$ and $\left.-41^{\circ} 27^{\prime} \mathrm{W}\right)$, during 15 days, in January, 2016. Larvae of the piabanha-of-Pardo, 24 hours posthatching, with total length of $7.82 \pm 0.46 \mathrm{~mm}$ and weight of $2.44 \pm 0.02 \mathrm{mg}$ obtained through induced breeding were counted individually and transferred to aquariums with $5 \mathrm{~L}$ volume, under constant aeration and stocking density of 15 larvae $\mathrm{L}^{-1}$.

Larvae were counted and divided into five treatments with different photoperiods: 0L:24D, 6L:18D, 12L12D, 18L:6D and 24L:0D (871.12 \pm 92.65 lux obtained 40W- fluorescent lamp). The experimental design was completely randomized, with five treatments and four repetitions, totaling 20 experimental units.

The control of the daylight hours was carried out by teams that lit the lights at $6 \mathrm{pm}$, and turned them off in the stipulated time. Tanks were covered with black plastic to prevent the incidence of light from other sources during the dark periods.

The larvae were fed during the first five days with 10 curimba larvae (Prochilodus hartii) per piabanha-of-Pardo larvae day ${ }^{-1}$, and commercial feed was offered in the third day of life, $10 \%$ of body weight, supplied at 9 am and 5 pm. For results reliability, the commercial feed used was bromatology analyzed, presenting in its composition (100\%): $55 \%$ crude protein (Kjeldhal) and, $4 \%$ fat, $1.5 \%$ phosphorous, and a maximum of $10.5 \%$ moisture content, $6 \%$ crude fiber, $18 \%$ mineral material, and $5 \%$ of calcium (AOAC, 2016).

The water temperature $\left({ }^{\circ} \mathrm{C}\right)$, dissolved oxygen (DO) $\left(\mathrm{mg} \mathrm{L}^{-1}\right)$, percentage of oxygen saturation $(\%), \mathrm{pH}$ and conductivity $\left(\mu \mathrm{S} \mathrm{cm}^{-1}\right)$ were monitored daily. Immediately after the limnological variables reading, the tanks were siphoned to remove the waste and held the exchange of $40 \%$ of the total water volume.
At the end of the experiment, the survival rates and biomass were determined. Next, 10 larvae of each repetition were euthanized $\left(286,55 \mathrm{mg} \mathrm{L}^{-1}\right.$ of eugenol) in accordance with Resolution No. 714 of 20/07/2002 the Federal Council and fixed in 10\% formalin for later biometrics weight in analytical balance 0.1 (Scientch AS 210) and standard length, obtained with a digital caliper (Starrett Universal Series 125 to $0.05 \mathrm{~mm}$ ). After that, the Fulton's condition factor was calculated by the expression: $\mathrm{K}$ $=\left(\right.$ weight standard length $\left.{ }^{-3}\right) \times 100$. Specific growth rate was used to calculate the expression: $\mathrm{SGR}=$ $100\left(\ln \mathrm{BW}_{\mathrm{f}}-\ln \mathrm{BW}_{\mathrm{i}}\right) \Delta \mathrm{t}^{-1} . \Delta \mathrm{t}$ is the duration in days between samples, $\mathrm{BW}_{\mathrm{i}}$ the initial body weight, and the $\mathrm{BW}_{\mathrm{f}}$ the final weight of each replica.

Data of the larvae were analyzed by linear regression and the minimum or maximum point value of each regression was obtained using the derived equation. The limnological parameters data were compared by ANOVA and rear Tukey's test $(\mathrm{P}<0.05)$, using the statistical program SAS 9.1.

\section{RESULTS AND DISCUSSION}

The limnological parameters (Table 1) were similar between photoperiods $(\mathrm{p}>0.05)$, and stable throughout the experiment, and the minimum and maximum values of the coefficient of variation, which oscillated among 6.0 and $9.7 \%$ for temperature, 6.8 for the $11.5 \% \mathrm{DO}$, of 4.2 to $5.2 \%$ for $\mathrm{pH}$, and 8.3 and $12.0 \%$ for the conductivity. Limnological parameters were within the range suitable for Brycon larviculture according to PEDREIRA et al. (2006; 2008), and close to the values considered acceptable for the growth of the piabanha-do-Pardo larvae by CORASPE AMARAL et al. (2012) and COSTA et al (2013).

Analyzing the figure 1 and its respective regression curves it can be described that the different photoperiods directly influenced the performance and the survival of the piaba-do-Pardo. Photoperiods with lowest incidence of light (0L: 24D) and higher light incidence (24L: 0D) tended to have lower survival, higher weight, and SGR and Fulton's condition factor.

The lowest survival in the smallest photoperiod was due to the piabanha-do-Pardo larva to be a visual predator (COSTA et al 2013). Already the larger photoperiod provides a longer viewing time from one larva to another increasing opportunity for cannibalism. COSTA et al (2013) also described that the survival to piabanha-do-Pardo was lower $(66.25 \%)$, with a higher rate of cannibalism $(17.08 \%)$, in the aquarium with light color when compared to the dark aquarium $(84.17 \%)$, with a 
Table 1 - Mean and standard deviation of temperature, dissolved oxygen, $\mathrm{pH}$, and electrical conductivity for the piabanha-of-Pardo larvae, submitted under different hours of light during the trial period.

\begin{tabular}{|c|c|c|c|c|}
\hline Parameters & OL:24D & 6L:18D & 12L:12D & 18L:6D \\
\hline Temperature $\left({ }^{\circ} \mathrm{C}\right)$ & $27.59 \pm 1.83$ & $26.88 \pm 1.79$ & $28.15 \pm 2.26$ & $28.15 \pm 2.73$ \\
\hline Dissolved oxygen $\left(\mathrm{mg} \mathrm{L}^{-1}\right)$ & $6.16 \pm 0.71$ & $7.11 \pm 0.57$ & $6.73 \pm 0.47$ & $6.79 \pm 0.67$ \\
\hline $\mathrm{pH}$ & $6.86 \pm 0.36$ & $7.04 \pm 0.34$ & $7.04 \pm 0.31$ & $7.04 \pm 0.31$ \\
\hline Conductivity $\left(\mu \mathrm{S} \mathrm{cm}^{-1}\right)$ & $87.34 \pm 8.01$ & $90.13 \pm 7.83$ & $90.66 \pm 7.56$ & $96.33 \pm 9.10$ \\
\hline
\end{tabular}

The water quality values showed no statistical difference $(\mathrm{P}>0.05)$ between different photoperiods.

low rate of cannibalism (6.25\%). However, for some fish species, total darkness or low light has led to higher survival and performance such as the larvae and juvenile of Clarias gariepinus (African catfish) (ADEWOLU et al., 2008) and Salminus brasiliensis (Golden) larvae (SCHÜTZ et al., 2007) respectively. According to NAVARRO et al. (2010), variations in the light intensity can induce specific adaptations to the environment, such as changes in natatory activity. The high swimming activity observed may be a response from the environmental stimuli with the physiological process, and needs to be better investigated.

The Brycon larvae have well developed and pigmented eyes, which are characteristic of fish that have greater ease in visually direct attack on their prey (MACIEL et al., 2010). Several authors have reported better larvae and fry performance by longer photoperiods, and increasing food consumption (MOUSTAKAS et al., 2004; BISWAS et al., 2006; BISWAS et al., 2008). According to LITVAK \& HANSELL (1990), larvae under continuous light can have more feeding opportunities and this can be reflected in increased growth. Probably, the longer light exposure may have allowed more prey consumption of piabanha larvae, and resulted in greater weight, length and SGR values. STEFANSSON et al. (1991) states that species such as Salmo salar (Atlantic salmon) exposed to long light periods are more efficient capturing prey.

The results with the piabanha, tropical species, are consistent with the tambaqui (Colossoma macropoтит), where longer photoperiods (24L:0D), provided greater performance in larvae (MENDONÇA et al., 2009). Also, long photoperiods provided better growth and survival rates for mulloway Argyrosomus (BALLAGH et al., 2008) and miiuy croaker Miichthys miiuy larvae (SHAN et al., 2008).
Larvae of piabanha subjected to a low photoperiod (6L:18D) have lower weight, length and SGR rates, which can be attributed to the fact that larvae feed more efficiently in the morning, with the presence of light, decreasing the visibility at 5 $\mathrm{pm}$, when the larvae remain in the dark, making it difficult to perceive live food. According to BISWAS \& TAKEUCHI (2003), tilapia larvae exposed to light for a short period were not able to synchronize their endogenous rhythms. For these authors, the photoperiod cycle can dissipate energy with a resultant decrease in growth; a short cycle of light may be responsible for a reduction in appetite.

Although, lighting is an important factor for catching food for fish, larvae of 0L:24D treatment showed better performance values (weight and length) when compared to treatment $6 \mathrm{~L}: 18 \mathrm{D}$, which can be explained by the fact that other factors also act in aid food collection, as mechanoreception or chemoreception and/or even the presence of the lateral line (COOMBS \& PATTON, 2009).

Lower growth rate of larvae reared in the dark (0L:24D) probably occurs by a reduction in the amount of food consumed by the larvae, which leads to lack of energy directed to growth. However, in a dark environment, the piabanha-of-Pardo larvae moved less, a condition that may have favored better growth in this environment when compared to 6L:18D. APPELBAUM \& KAMLER (2000) reported greater performance of $C$. gariepinus larvae in dark environment to promote lower energy costs with locomotion.

Lower SGR rates were observed in larvae subjected to low a photoperiod (6L:18D) treatment. FREITAS et al. (2009) reported higher SGR values for king fish (Odontesthes argentinensis) larvae in greater photoperiods. According to these authors, the 

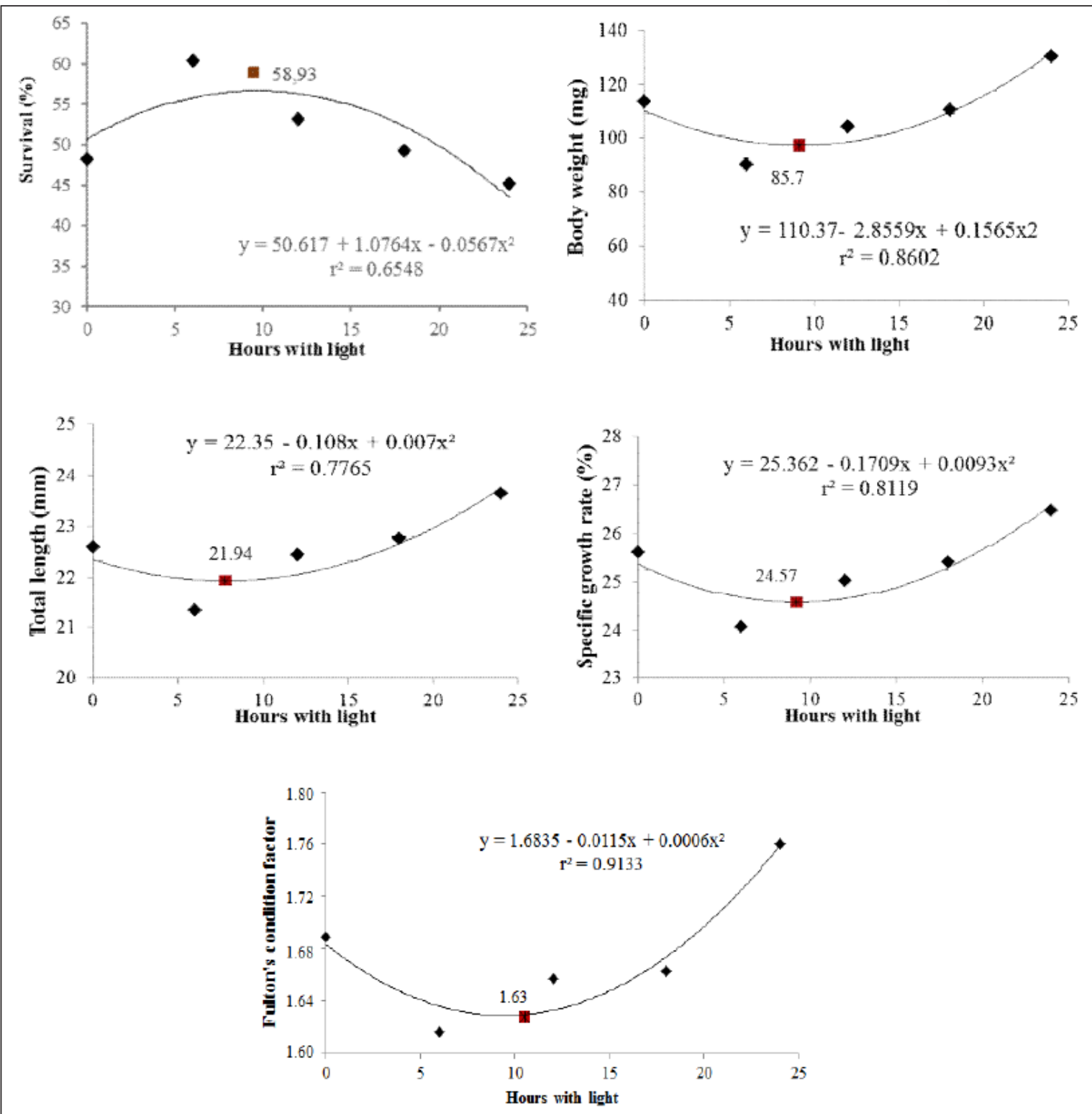

Figure 1 - Data of survival, body weight, total length, specific growth rate (SGR), and Fulton's condition factor (K) of piabanha-ofPardo larvae reared in different photoperiods. The empty point is the highest or lowest calculated value Regressions with significance level of 0.05 .

low growth rate of larvae reared in the dark was due to a reduction in the amount of food consumed by the larvae, which led to a lack of energy that should be directed to growth. MENDONÇA et al. (2009) also observed higher SGR values for tambaqui (C. macropomum) larvae in a larger photoperiod. However, contrary results were observed for catfish species with higher SGR rates for dark environments (PIAIA et al., 1999).
However, Fulton's condition factor, an indicator of the degree of fish welfare (ROSSI et al., 2007) was lower at the $6 \mathrm{~L}: 18 \mathrm{D}$ photoperiod than the 24L:0D. Lower values of Fulton's condition factor (minimum) were found to an intermediate photoperiod around 11 hours of light per day, obtained by derivative of the equation. FREITAS et al. (2009) reported that greater Fulton's condition factor values were observed for the $18 \mathrm{~L}: 6 \mathrm{D}$ and the 
24L:0D photoperiods, than in the $12 \mathrm{~L}: 12 \mathrm{D}$ and the OL:24D photoperiods. Photoperiods with 6 and 11 hours of light per day should be viewed with caution in the larval rearing of this species.

Larvae of treatments $0 \mathrm{~L}: 24 \mathrm{D}$ and $6 \mathrm{~L}: 18 \mathrm{D}$ showed less movement in the tank, which probably reduced the encounter with larvae sisters and consequently cannibalism, and conversely increased survival. This same condition was observed for golden catfish larvae (SCHÜTZ \& NUÑER, 2007; CAMPAGNOLO \& NUÑER, 2008). For some species of catfish with nocturnal habits, an increased photoperiod entails high drive, with energy expenditure and consequent reduction in survival (APPELBAUM \& KAMLER, 2000; ALMAZÁNRUEDA et al., 2005).

According to CAMPAGNOLO \& NUÑER (2008), rearing catfish larvae (Pseudoplatystoma corruscans) in a long photoperiod resulted in lower survival rates due to the intense activity of swimming larvae with higher energy consumption in these environments. Agreeing to these results, continuous dark would be better because a fish has difficulty to capture the other, reducing cannibalism with a consequent increase in survival. Asian sea bass (Lates calcarifer) reared under continuous darkness was more uniform in size than fish reared under continuous light conditions. This homogeneity diminishes the cannibalism because of the fact that a potential predator can swallow a prey up to a maximum of $67 \%$ of its own body length (APPELBAUM \& AROCKIARAJ, 2010).

SCHÜTZ et al. (2008) reported higher survivalvalues for the suruvi larvae(Steindachneridion scriptum) in intermediate (14L:8D) and continuous (24L:0D) photoperiods. In a dark environment, larvae are unable to detect the presence of food.

\section{CONCLUSION}

The 9L:15D photoperiod, specified by the derived equation, is indicated for the piabanha rearing, but researches with the species and the ideal photoperiod need to be better studied.

Piabanha-of-Pardo larvae have better survival rate at intermediate photoperiods, indicating photoperiods among 6 and 12 hours of light per day. Short photoperiods should be avoided, because they promote low survival in piabanha larviculture.

\section{ACKNOWLEDGMENT}

To Fundação de Amparo à Pesquisa do Estado de Minas Gerais (FAPEMIG/APQ-01437-13), Coordenação de Aperfeiçoamento de Pessoal de Nível Superior (CAPES/ Bolsa de Mestrado Cota Institucional), Conselho Nacional de Desenvolvimento Científico e Tecnológico (CNPq/Edital CICT 001 PIBIC/CNPq 2014) and Banco do Nordeste do Brasil (FUNDECI 2012/0324) for research aid granted.

\section{REFERENCES}

ADEWOLU, M. et al. Feed utilization, growth and survival of Clarias gariepinus (Burchell 1822) fingerlings cultured under different photoperiods. Aquaculture, v.283, n.1-4, p.64-67, 2008. Available from: $<$ http://www.sciencedirect.com/science/article/pii/ S0044848608005048>. Accessed: Feb. 21, 2016. doi: 10.1016/j. aquaculture.2008.07.020.

ALMAZÁN-RUEDA, P. et al. Photoperiod affects growth, behavior and stress variables in Clarias gariepinus. Journal of Fish Biology, v.67, n.4, p.1029-1039, 2005. Available from: <http://onlinelibrary. wiley.com/doi/10.1111/j.0022-1112.2005.00806.x/abstract $>$. Accessed: May 04, 2016. doi: 10.1111/j.0022-1112.2005.00806.x.

AOAC - ASSOCIATION OF OFFICIAL ANALYTICAL CHEMISTRY. Official methods of analysis. 20th ed. Arlington: AOAC International, 2016. 3172p.

APPELBAUM. A.S.; KAMLER. E. Survival, growth, metabolism and behavior of Clarias gariepinus (Burchell 1822) early stages under different light conditions. Aquacultural Engineering, v.22, n.4, p.269-287, 2000. Available from: <http://www.sciencedirect. com/science/article/pii/S0144860900000546>. Accessed: Feb. 25, 2016. doi: 10.1016/S0144-8609(00)00054-6.

APPELBAUM, S; AROCKIARAJ, A.J. Sibling cannibalism in juvenile Asian sea bass (Lates calcarifer) reared under different photoperiods. AACL Bioflux, v.3, n.5, p.384-392, 2010. Available from: < http://www.bioflux.com.ro/docs/2010.3.384-392.pdf>. Accessed: Apr. 8, 2016.

BALLAGH, D.A. et al. Photoperiod and feeding interval requirements of juvenile mulloway, Argyrosomus japonicas. Aquaculture, v.277, n.1-2, p.52-57, 2008. Available from: <http:// www.sciencedirect.com/science/article/pii/S0044848608001051>. Accessed: Mar. 18, 2016. doi: 10.1016/j.aquaculture.2008.02.025.

BEZERRA, K.S. et al. Crescimento e sobrevivência da tilápia chitralada submetida a diferentes fotoperíodos. Pesquisa Agropecuária Brasileira, v.43, n.6, p.737-743, 2008. Available from: $<\mathrm{http}$ //www.scielo.br/scielo.php?script=sci arttext\&pid=S0100-204X2008000600010>. Accessed: Mar. 20, 2016. doi: 10.1590/S0100-204X2008000600010.

BISWAS, A.K. et al. Effect of photoperiod manipulation on the growth performance and stress response of juvenile red sea bream (Pagrus major). Aquaculture Research, v.258, n.1-4, p.350 356, 2006. Available from: <www.sciencedirect.com/science/ article/pii/S0044848606002493>. Accessed: Mar. 09, 2016. doi: 10.1016/j.aquaculture.2006.03.048.

BISWAS, A.K. et al. Stimulation of growth performance without causing stress response in young red sea bream, Pagrus major (Temminck \& Schlegel), by photoperiod manipulation. Aquaculture Research, v.39, n.1-4, p.457-463, 2008. Available from: <http://onlinelibrary.wiley.com/doi/10.1111/j.13652109.2008.01897.x/abstract>. Accessed: Apr. 19, 2016. doi: 10.1111/j.1365-2109.2008.01897.x. 
BISWAS, A.K.; TAKEUCHI, T. Effects of photoperiod and feeding interval on food intake and growth rate of Nile tilapia Oreochromis niloticus L. Fisheries Science, v.69, n.5, p.1010-1016, 2003. Available from: <http://onlinelibrary.wiley.com/doi/10.1046/ j.1444-2906.2003.00720.x/abstract>. Accessed: Mar. 9, 2016. doi: 10.1046/j.1444-2906.2003.00720.x.

CAMPAGNOLO, R.; NUÑER, A.P.O. Survival and growth of Pseudoplatystoma corruscans (Pisces - Pimelodidae) larvae: effect of photoperiod. Arquivo Brasileiro de Medicina Veterinária e Zootecnia, v.60, n.6, p.1511-1516, 2008. Available from: $\quad<$ http://www.scielo.br/scielo.php?script=sci_arttext\&pid $=$ S0102-09352008000600030 $>$. Accessed: Mar. 14, 2016. doi: 10.1590/S0102-09352008000600030.

COOMBS, S.; PATTON, P. Lateral line stimulation patterns and prey orienting behavior in the Lake Michigan mottled sculpin (Cottus bairdi). Journal of Comparative Physiology, v.195, n.3, p.279-297, 2009. Available from: <https://link.springer.com/ article/10.1007/s00359-008-0405-4>. Accessed: Mar. 11, 2016. doi: 10.1007/s00359-008-0405-4.

CORASPE-AMARAL, M.V. et al. Time of feed transition and inclusion levels of exogenous protease in rations for piabanha-doPardo Brycon sp. hatchery. Acta Scientiarum: Animal Science, v.34, n.4, p.347-353, 2012. Available from: <http://periodicos.uem. br/ojs/index.php/ActaSciAnimSci/article/view/14471>. Accessed: Feb. 11, 2016. doi: 10.4025/actascianimsci.v34i4.14471.

COSTA, D.C. Larvicultura de Brycon sp. (piabanha-do-Pardo) sob distintas cores de aquários e fotoperíodos. Dissertação (Mestrado) - Programa de Pós-Graduação em Zootecnia, Universidade Federal dos Vales do Jequitinhonha e Mucuri, 2011.

COSTA, D.C. et al. Larvicultura de piabanha-do-pardo em aquários de cores diferentes. Pesquisa Agropecuária Brasileira, v.48, n.8, p.1005-1011, 2013. Available from: <http://www.scielo.br/ scielo.php?script=sci_arttext\&pid=S0100-204X2013000800031>. Accessed: Feb. 11, 2016. doi: 10.1590/S0100-204X2013000800028.

FREITAS, L.S. et al. Effects of photoperiod on survival and growth of the marine pejerrey, Odontesthes argentinensis larvae. Aquaculture Research, v.40, n.2, p.252-255, 2009. Available from: <http://www.onlinelibrary.wiley.com/doi/10.1111/j.13652109.2008.02080.x/full>. Accessed: Feb. 11, 2016. doi: 10.1590/ S0100-204X2013000800028.

HILSDORF, A.W.S. et al. Brycon insignis Steindachner (1877). In: MACHADO, A.B.M.; DRUMMOND, M.G., PAGLIA, A.P. Livro vermelho da fauna brasileira ameaçada de extinção. Brasília: MMA, 2008. p.48-50.

LITVAK, M.K.; HANSELL, R.I.C. Investigation of food habit and niche relationships in a cyprinid community. Canadian Journal of Zoology, v.68, n.9, p.1873-1879, 1990. Available from: <http://www. nrcresearchpress.com/doi/abs/10.1139/z90-267?journalCode=cjz\#. WfnpWojJOhc>. Accessed: Feb. 10, 2016. doi: 10.1139/z90-267.

MACIEL, C.M.R. et al. Morphological and behavioral development of the piracanjuba larvae. Revista Brasileira de Zootecnia, v.39, n.5, p.961-970, 2010. Available from: <http://www.scielo.br/ scielo.php?script=sci_arttext\&pid=S1516-35982010000500004 $>$. Accessed: Feb. 13, 2016. doi: 10.1590/S1516-35982010000500004.

MENDONÇA, P. P. et al. Influência do fotoperíodo no desenvolvimento de juvenis de tambaqui (Colossoma macropomum).
Archivo de Zootecnia, v.58, n.223, p.323-331, 2009. Avaiable from: $<$ http://scielo.isciii.es/scielo.php?script=sci_arttext\&pid $=$ S0004-05922009000300001>. Accessed: Apr. 18, 2016.

MOUSTAKAS, C.T.H. et al. Combined effects of photoperiod and salinity on growth, survival, and osmoregulatory ability of larval southern flounder Paralichthys lethostigma. Aquaculture, v.229, n.1-4, p.159-179, 2004. Available from: <http://www. sciencedirect.com/science/article/pii/S0044848603003661>. Accessed: Mar. 18, 2016. doi: 10.1016/S0044-8486(03)00366-1.

PEDREIRA, M.M. et al. Larvicultura de matrinxã em tanques de diferentes cores. Pesquisa Agropecuária Brasileira, v.43, n.10, p.1365-136, 2008. Available from: <http:// www.scielo.br/scielo.php? script $=$ sci arttext\&pid $=$ S0100204X2008001000015>. Accessed: Mar. 18, 2016. doi: 10.1590/ S0100-204X2008001000015.

PEDREIRA, M.M. et al. Influência do formato do aquário na sobrevivência e no desenvolvimento de larvas de matrinxã Brycon cephalus (Osteichthyes, Characidae). Revista Brasileira de Zootecnia, v.35, n.2, p.329-333, 2006. Available from: $<$ http://www.scielo.br/scielo.php?script=sci_arttext\&pid $=$ S1516-35982006000200001 $>$. Accessed: Mar. 19, 2016. doi: 10.1590/S1516-35982006000200001.

PIAIA, R. et al. Growth and survival of fingerlings of silver catfish exposed to different photoperiods. Aquaculture International, v.7, n.3, p.201-205, 1999. Available from: <https://link.springer. com/content/pdf/10.1023/A:1009299830102.pdf $>$. Accessed: Feb. 11, 2016. 10.1023/A:1009299830102.

ROSSI, R.M. et al. Estimação do fator de condição de peixes da espécie Tracydoras paraguayensis: uma perspectiva bayesiana. Acta Scientiarum, v.29, n.1, p.85-92, 2007. Avaiable from: $<$ http://periodicos.uem.br/ojs/index.php/ActaSciAnimSci/ article/view/263>. Accessed: Mar. 10, 2016. doi: 0.4025/ actascianimsci.v29i1.263.

SCHÜTZ. J. H.; NUÑER. A. P. O. Growth and survival of Dourado Salminus brasiliensis (Pisces, Characidae) post-larvae cultivated with different types of food and photoperiods. Brazilian Archives of Biology and Technology, v.50, n.3, p.435-444, 2007. Available from: $<$ http://www.scielo.br/scielo.php?script=sci artte xt\&pid=S1516-89132007000300010 $>$. Accessed: Mar. 13, 2016. doi: 10.1590/S1516-89132007000300010.

SCHÜTZ, J.H. et al. Crescimento e sobrevivência de larvas de suruvi Steindachneridion scriptum nos primeiros dias de vida: influência de diferentes alimentos e fotoperíodos. Boletim do Instituto de Pesca, v.34, n.3, p.443-451, 2008. Available from: $<$ http://www.pesca.sp.gov.br/34_3_443-451.pdf $>$. Accessed: Apr. 13, 2016.

SHAN. X. et al. Effects of photoperiod on growth. mortality and digestive enzymes in miiuy croaker larvae and juveniles. Aquaculture, v.281, n.1-4, p.70-76, 2008. Available from: $<w w w$. sciencedirect.com/science/article/pii/S0044848608004018>. Accessed: Apr. 15, 2016. doi: 10.1016/j.aquaculture.2008.05.034.

STEFANSSON, S.O. et al. Growth parr-smolt transformation, and changes in growth hormone of Atlantic salmon Salmo salar, reared under different photoperiods. Canadian Journal of Fisheries and Aquatic Sciences, v.48, n.11, p.2100-2108, 1991. Available from: $<$ http://www.nrcresearchpress.com/doi/abs/10.1139/f91-249\#. WfisrWhSzIU>. Accessed: Apr. 16, 2016. doi: 10.1139/f91-249. 